\title{
ROAD DENSITY AND POTENTIAL IMPACTS ON WILDLIFE SPECIES SUCH AS AMERICAN MOOSE IN MAINLAND NOVA SCOTIA
}

\author{
KAREN F. BEAZLEY*1, TAMAINI V. SNAITH ${ }^{2}$, \\ FRANCES MACKINNON ${ }^{3}$, and DAVID COLVILLE ${ }^{4}$ \\ 1 School for Resource and Environmental Studies, \\ Dalhousie University, Halifax, N.S., B3H 3J5 \\ ${ }^{2}$ Department of Anthropology, \\ Harvard University, Peabody Museum, \\ Cambridge, MA. 02138 \\ ${ }^{3}$ Nova Scotia Department of Natural Resources, \\ Wildlife Division, Kentville, N.S. B4N 4E5 \\ ${ }^{4}$ Applied Geomatics Research Group, \\ Centre of Geographic Sciences, Nova Scotia Community College, \\ Lawrencetown, N.S. BOS $1 \mathrm{MO}$
}

\begin{abstract}
Habitat conversion, degradation and fragmentation, and the introduction of exotic species are among the primary factors causing the loss of biodiversity. Road density is a valuable indicator of these anthropogenic factors. Deleterious biological effects extend more than 1000 metres from roads, and road density of $0.6 \mathrm{~km} / \mathrm{km}^{2}$ has been identified as an apparent threshold value above which natural populations of certain large vertebrates decline. Road density assessments in Nova Scotia indicate that many areas exceed this threshold. Multivariate logistic regression analyses indicate relationships between road density, moose pellet distribution, and habitat suitability values. Road density has a statistically significant negative correlation with moose pellets, such that as road density increases, the probability of moose pellet presence decreases. Road density alone and road density in combination with habitat suitability index values predict the presence of moose pellets, whereas habitat suitability values alone do not. Thus, road density may be an indicator of moose habitat selection or effectiveness in mainland Nova Scotia. Biodiversity conservation activities in Nova Scotia and elsewhere could focus on discouraging further road densities above $0.6 \mathrm{~km} / \mathrm{km}^{2}$; protecting remaining roadless and low road density areas; minimizing new road construction, especially in natural areas; decommissioning and regenerating old logging roads; increasing buffer zones between natural areas and roads; and providing road crossings for wildlife in the form of under and overpasses.
\end{abstract}

La conversion, la dégradation et la fragmentation des habitats ainsi que l'introduction d'espèces exotiques figurent parmi les principaux facteurs responsables de la réduction de la biodiversité. La densité routière est un indicateur précieux de ces facteurs anthropiques. Des effets biologiques négatifs se font sentir à plus de 1000 mètres des routes, et il semble qu'une densité routière de $0,6 \mathrm{~km} / \mathrm{km}^{2}$ constitue un seuil au-dessus duquel les populations naturelles de certains gros vertébrés diminuent. En Nouvelle-Écosse, la densité routière dépasse ce seuil dans plusieurs régions. Des analyses de régression logistique multivariée révèlent des relations entre la densité routière, la répartition des excréments d'orignaux et les valeurs de qualité de l'habitat. Il existe une corrélation négative significative entre la densité routière et les excréments d'orignaux, l'augmentation de la densité routière réduisant la probabilité de la présence d'excréments. La densité routière seule et la densité routière combinée aux valeurs de l'indice de qualité de l'habitat permettent de prévoir la présence d'excréments d'orignaux, tandis que les valeurs de qualité de l'habitat seules ne peuvent le faire. Par conséquent, la densité routière peut être un indicateur du choix ou de l'utilité de l'habitat pour l'orignal dans la partie continentale de la Nouvelle-Écosse. Dans cette province et ailleurs, les activités de conservation de la biodiversité pourraient mettre l'accent sur le maintien de la densité routière à moins de $0,6 \mathrm{~km} / \mathrm{km}^{2}$, sur la protection des zones sans route et à faible densité routière, sur la réduction de la construction de nouvelles routes, en particulier dans les régions naturelles, sur la mise hors-service et la restauration des vieux chemins d'exploitation forestière, sur l'augmentation des zones tampons entre les régions naturelles et les routes et sur l'aménagement de traversées routières (tunnels et viaducs) pour les animaux sauvages.

\footnotetext{
* Author to whom correspondence should be addressed.
} 


\section{Introduction}

Currently, $10-40 \%$ of the world's species are at risk of extinction (Pimm et al. 1995, May et al. 1997, Pimm et al. 2001). In Canada alone, 441 species and populations were listed as extinct, extirpated, endangered, threatened or of special concern in 2003 (COSEWIC 2003). In Nova Scotia, large mammals such as the woodland caribou, wolf, and cougar have already been extirpated, while Canada lynx, American marten, American moose and several other species are considered to be at risk (CESCC 2001).

Conversion, fragmentation and degradation of wildlife habitat by human activities are among the primary factors causing species to decline, along with over-exploitation and the invasion of exotic or introduced species (Soule 1991). These factors are frequently associated with increases in road density (Noss 1995, Forman et al. 1997, Jalkotzy et al. 1997). Roads have a generally negative overall impact on native biological diversity and ecological integrity (Brocke et al., 1988, Jalkotzy et al. 1997, Gucinski et al. 2001). This includes the deterioration of wildlife habitat, hydrology, geomorphology, and air quality, increased competition and predation (including by humans), and the loss of naturalness or pristine qualities (Forman et al. 1997, Jalkotzy et al. 1997). Roadless areas and areas with low road density are more likely to have greater ecological integrity and/or wildlife habitat value than similar areas with more roads (Noss 1995, Rudis 1995). For species that are sensitive to human activities, such as large mammals and birds, especially herbivores and carnivores, road density is often the most accurate predictor of habitat effectiveness (Lyon 1983, Thiel 1985, Noss \& Cooperrider 1994, Noss et al. 1999). Road density has, as a result, been suggested as an appropriate index of human activity and land-use intensity, and as a counter-indicator of suitable habitat for large vertebrates and ecological integrity (Noss 1995, Rudis 1995, Forman 1995, Forman et al. 1997, Noss et al. 1999). This type of surrogate measure is useful where the maintenance or monitoring of biological diversity or ecological integrity are among the objectives, such as regional planning, park, forestry and wildlife management, and protected area system design.

Relatively little research has been conducted to examine the effects of roads on biodiversity and ecological integrity in Canada. This paper focuses on the effects of road density on selected mammals that are found in Nova Scotia by examining results reported in the literature from research conducted elsewhere and with reference to a study on moose and road density in Nova Scotia (Snaith 2001, Snaith et al. 2004). First, examples of road effects and road density thresholds for large and medium-sized mammals are briefly summarized from the literature. Second, results of a GIS-based road density classification and mapping exercise in Nova Scotia are presented. Third, the correlation of road density and habitat suitability with the distribution of moose pellets on mainland Nova Scotia is described to illustrate the possible impact of road density on moose habitat selection, and its utility as a surrogate measure of the effects of human land use on habitat suitability or effectiveness. Finally, general recommendations are made for incorporating road density considerations into biodiversity conservation, and minimizing road effects in Nova Scotia and elsewhere.

\section{Impacts of roads on wildlife}

The impact of linear disturbance, (including major highways, primary and secondary roads, trails, railroads, and other development corridors such as pipelines) on wildlife is well documented in the scientific literature. Roads lead to both direct and 
indirect mortality of wildlife, disturb ranging patterns, and reduce and fragment habitat (Noss 1995, Forman et al. 1997, Jalkotzy et al. 1997). Roads provide access for competitors, predators, and exotic species, increase hunting pressure, and increase mortality by vehicle collision (Houston 1968, Prescott 1968, Peek et al. 1987, Hogg 1990, Forman et al. 1997, Jalkotzy et al. 1997, Rempel et al. 1997, Gucinski et al. 2001). Increased human access to remote areas results in more hunting, trapping, fishing and poaching, disturbance to wildlife, and damage to ecosystems (Brocke et al. 1988, Forman and Hersperger 1996, Gucinski et al. 2001). Roads cause erosion and downstream sedimentation, which lead to changes in vegetation and habitat structure, and the degradation of fish habitat (Gucinski et al. 2001). These negative effects have been shown to extend more than 1000 metres from the road (Forman 1995, Forman et al. 1997). The effects of roads on wildlife can be characterized as of three general types: 1) individual and habitat disruption and habitat avoidance; 2) social disruption and population effects; and, 3) direct and indirect mortality (reclassified from Jalkotzy et al. 1997) (Table 1).

Table 1 Categories of disturbance effects of linear corridors on wildlife

1. Individual and habitat disruption and habitat avoidance

Wildlife leave or avoid an area or alter their patterns of use, often with a cost in energy expenditure or lost opportunities. In this case, the habitat is effectively unavailable to wildlife.

2. Social disruption and population effects

Disruption may occur in the structure of a population as a result of the disturbance corridor; for example, differential mortality among classes, or changes in group structure. Behavioral responses to disturbances may have demographic consequences.

3. Direct and indirect mortality

Direct mortality may arise from wildlife-vehicle collisions, and indirect mortality may arise from, for example, increased access by humans, predators and competitors.

Compiled and adapted from Jalkotzy et al. (1997)

Due to the lack of empirical information on the effects of roads on wildlife in Nova Scotia, a synthesis of the literature from research conducted elsewhere is a useful starting point for assessing potential local impacts. Vertebrate species that are also found in Nova Scotia, such as moose, black bear, white-tailed deer, marten, lynx, bobcat and river otter, have been shown in studies elsewhere to suffer direct mortality as a result of roads. For example, Jalkotzy et al. (1997) report that deer and river otter frequently suffer collision mortality, vehicle and train collisions are the second largest human-caused source of mortality for moose and, in some areas, roadkill mortality may be the single largest cause of death for black bear and may even threaten populations. While the number of road-related mortalities for these species in Nova Scotia is not known, it is reasonable to hypothesize that as road densities increase, the direct and indirect mortality and its potential negative effects on populations of certain species will also increase until the populations decline.

Increasing road access leads to greater indirect mortality through increased hunting, trapping, poaching, predation, competition, and parasitism of species (Brocke et al. 1988, Jalkotzy et al. 1997, Gucinski et al. 2001). Species affected include, among others, moose, black bear, marten, lynx, bobcat, river otter, and birds. For example, field studies have demonstrated that black bear are increasingly vulnerable to hunting as road density increases (Brody and Pelton 1989). Moose population viability has also been shown to be vulnerable to increased hunting pressure near roads, particularly 
illegal hunting (Lyon 1984, Boer 1990). In Quebec and Ontario, overharvest of moose occurred in areas with greater road access (Timmerman \& Gollath 1982, Jalkotzy et al. 1997). A study in New Brunswick found that $92 \%$ of moose killed by hunters occurred within $1 \mathrm{~km}$ of forest roads (Boer 1990); since the vast majority of moose killed in New Brunswick are killed near roads, "road density affects moose harvest and hence moose population" (Boer 2002). In Newfoundland, unpublished data derived from 35 years of hunter reports have been used by the provincial government's game management agency to correlate hunter access, moose-hunting success, and moose sightings (McLaren 2002). Reports of hunting success were also tracked as access was provided to new areas over a period of about six years, from 1989 to 1995 . The records from Newfoundland illustrate that "with increasing road access (and high hunting success enjoyed by Newfoundland hunters), moose density decreases" (ibid).

Roads also cause habitat avoidance, disrupt natural ranging patterns and lead to the fragmentation of populations and habitat, which result in changes in species distributions and population viability (Lyon 1984, Gucinski et al. 2001). Populations are fragmented into smaller subpopulations, which are vulnerable to environmental and demographic fluctuations, inbreeding depression and associated losses of genetic variability, and ultimately local extirpation (e.g., Terborgh \&Winter 1980, Shaffer 1981, Gilpin \& Soulé 1986). Both bear and moose have been shown to avoid habitat near roads and trails (Forman et al. 1997, Jalkotzy et al. 1997). For example, female black bears in Arkansas utilized habitat within $240 \mathrm{~m}$ of roads less than expected, and to black bears in northwestern Montana avoided areas within $274 \mathrm{~m}$ of roads and trails in the spring and within $914 \mathrm{~m}$ of roads during fall (Jalkotzy et al. 1997). In a telemetry study, black bears were found to almost never cross major highways, and crossed roads with low traffic volumes more frequently than those with higher traffic volumes (Brody and Pelton 1989). In Alberta, moose were deflected by snow banks averaging $65 \mathrm{~cm}$ along primary roads (Jalkotzy et al. 1997). Road construction, maintenance, and road traffic disturb moose, which often avoid or leave the area (Timmerman \& Gollath 1982, Forman et al. 1997, Jalkotzy et al. 1997).

Low-intensity linear developments such as hiking and other recreational trails also disrupt ranging patterns and pose a threat to some species (Knight \& Gutzwiller 1995, Miller et al. 1998). Reproductive success and population density of sensitive species such as large herbivores decline as recreational access increases, often as a learned response stemming from hunting pressure (Noss et al. 1999). For example, after cross-country ski development in Elk Island National Park, moose numbers within $500 \mathrm{~m}$ of ski trails decreased from pre-development figures (Jalkotzy et al. 1997).

In some cases, it can be argued that roads improve habitat quality by creating new forage areas. Linear development through closed-canopy forest creates edge openings where new growth may create attractive browse areas for herbivores and, in turn, attract predators. Increasing mortality and a likely cascade of other adverse effects, however, may outweigh any benefits of increased forage availability (Jalkotzy et al. 1997, Gucinski et al. 2001). Moose, for example, frequently do not take advantage of the increased forage availability provided by forestry and other roads, including those that are not accompanied by settlement or agriculture (Jalkotzy et al. 1997, Timmerman \& Gollath 1982, Forman et al. 1997). Moose in Nova Scotia may also be subject to increased mortality from competition and introduction of the parasite, Paralephostrongylus tenuis, associated with white-tailed deer, which invade moose habitat along forest roads, road verges, and other linear canopy openings (Telfer 1968, Prescott 1974, Telfer \& Cairns 1986, Pulsifer \& Nette 1995, and for an overview refer to Snaith \& Beazley (2004)). 
Roads are often the avenue and may be the first means by which exotic species invade natural landscapes (Schowalter 1988, Noss \& Cooperrider 1994, Forman 1995, Noss et al. 1999, Gucinski et al. 2001). Biological invasions are promoted by disturbance to natural ecosystems such as road construction; and roads and road verges serve as corridors along which exotic species such as invasive plants, pathogenic fungi, and certain animals may disperse (Schowalter 1988, Hobbs \& Huenneke 1992, Noss \& Cooperrider 1994, Forman 1995). Invading species are generally opportunistic and aggressive and may prey upon or out-compete sensitive and less-aggressive local species (Williamson \& Fitter 1996). Natural predators or controls may also be absent for exotic species in the newly invaded area, and exotics may not provide the forage and other necessary resources for other species that local species provide (Usher 1988, Williamson \& Fitter 1996).

The effect of roads on most medium-sized carnivores is poorly documented (Jalkotzy et al. 1997). American marten, lynx and fisher all generally avoid human developments and presence, and are more common where human densities are low. In boreal forests in Ontario, marten in logged areas with associated road networks had lower mean ages, were less productive, and suffered higher trapping mortality than those in unlogged forests (ibid.). Lynx avoid crossing major highways and hunting in open areas (ibid.). Declines in lynx populations in Nova Scotia may also be linked to forest trail, road and causeway construction, which facilitates dispersal of competitors such as coyote and bobcat into lynx habitat (O'Neil 2000, Anonymous 2000, Buskirk et al. 2000).

\section{Road density thresholds for wildlife species survival}

There are many reports suggesting that, in general, many wildlife species are negatively affected by roads (Lyon 1983, Thiel 1985, Noss \& Cooperrider 1994, Forman 1995, Jalkotzy et al. 1997, Noss et al. 1999, Gucinski et al. 2001). As road density increases, so does the likelihood of native species extirpation. The probability of extirpation is correlated to body size, with larger animals becoming extirpated at lower road densities (Forman et al. 1997). Field studies suggest that medium and large-sized vertebrates, including moose, black bear, and white-tailed deer, are adversely affected by increasing road density (Lyon 1983, Thiel 1985, Boer 1990, Jalkotzy et al. 1997, Crete et al. 1981, Timmermann \& Gallath 1982, Sage et al. 1983). Forman et al. (1997) have suggested that there is a maximum or threshold road density $\left(0.6 \mathrm{~km} / \mathrm{km}^{2}\right)$ for a "naturally functioning landscape containing sustained populations" of large mammals. Above this threshold, some large mammal populations decline due to disturbance effects and increased mortality. Threshold density values above which wildlife cannot tolerate further road disturbance have been suggested for some species, ranging from 0.25 to $1.9 \mathrm{~km} / \mathrm{km}^{2}$ (Table 2 ). 
Table 2 Summary of road density thresholds for wildlife species and ecosystems

\begin{tabular}{|c|c|c|}
\hline $\begin{array}{l}\text { Species } \\
\text { (Location) }\end{array}$ & $\begin{array}{l}\text { Road density } \\
\text { (mean, guideline, threshold) }\end{array}$ & Reference \\
\hline $\begin{array}{l}\text { Wolf } \\
\text { (Minnesota) }\end{array}$ & $\begin{array}{l}0.36 \mathrm{~km} / \mathrm{km}^{2} \\
\text { (mean road density in } \\
\text { primary range) } \\
0.54 \mathrm{~km} / \mathrm{km}^{2} \\
\text { (mean road density in } \\
\text { peripheral range) }\end{array}$ & Mech et al. 1988 \\
\hline Wolf & $\begin{array}{l}>0.6 \mathrm{~km} / \mathrm{km}^{2} \\
\text { (absent at this density) }\end{array}$ & Jalkotzy et al. 1997 \\
\hline $\begin{array}{l}\text { Wolf } \\
\text { (Wisconsin) }\end{array}$ & $\begin{array}{l}0.45 \mathrm{~km} / \mathrm{km}^{2} \\
\text { (limited to areas of pack-area } \\
\text { mean road density at or below } \\
\text { this level) }\end{array}$ & Lyon 1984 \\
\hline $\begin{array}{l}\text { Wolf, Mountain lion } \\
\text { (Minnesota, Wisconsin, } \\
\text { Michigan) }\end{array}$ & $\begin{array}{l}0.6 \mathrm{~km} / \mathrm{km}^{2} \\
\text { (apparent threshold value for a } \\
\text { naturally functioning landscape } \\
\text { containing sustained populations) }\end{array}$ & $\begin{array}{l}\text { Thiel 1985, Van Dyke } \\
\text { et al. 1986, Jensen et al. } \\
\text { 1986, Mech et al. 1988, } \\
\text { Mech } 1989\end{array}$ \\
\hline $\begin{array}{l}\text { Elk } \\
\text { (Idaho) }\end{array}$ & $\begin{array}{l}1.9 \mathrm{~km} / \mathrm{km}^{2} \\
\text { (density standard for habitat } \\
\text { effectiveness) }\end{array}$ & Woodley 2000 \\
\hline $\begin{array}{l}\text { Elk } \\
\text { (Northern United States) }\end{array}$ & $\begin{array}{l}1.24 \mathrm{~km} / \mathrm{km}^{2} \\
\text { (habitat effectiveness decline by at } \\
\text { least } 50 \% \text { ) }\end{array}$ & Lyon, 1984 \\
\hline $\begin{array}{l}\text { Elk, Bear, Wolverine, } \\
\text { Lynx, and others }\end{array}$ & $\begin{array}{l}0.63 \mathrm{~km} / \mathrm{km}^{2} \\
\text { (reduced habitat security and } \\
\text { increased mortality) }\end{array}$ & Woodley 2000 \\
\hline $\begin{array}{l}\text { Black bear } \\
\text { (North Carolina) }\end{array}$ & $\begin{array}{l}>1.25 \mathrm{~km} / \mathrm{km}^{2} \text { (open roads) } \\
>0.5 \mathrm{~km} / \mathrm{km}^{2} \text { (logging roads) } \\
\text { (interference with use of habitat) }\end{array}$ & Brody and Pelton 1989 \\
\hline Black bear & $\begin{array}{l}0.25 \mathrm{~km} / \mathrm{km}^{2} \\
\text { (road density should not exceed) }\end{array}$ & Jalkotzy et al. 1997 \\
\hline $\begin{array}{l}\text { Bobcat } \\
\text { (Wisconsin) }\end{array}$ & $\begin{array}{l}1.5 \mathrm{~km} / \mathrm{km}^{2} \\
\text { (density of all road types in } \\
\text { home range) }\end{array}$ & Jalkotzy et al. 1997 \\
\hline Category & Road density & Reference \\
\hline $\begin{array}{l}\text { Extremely high } \\
\text { High } \\
\text { Moderate } \\
\text { Low } \\
\text { Very low }\end{array}$ & $\begin{array}{l}>3 \mathrm{~km} / \mathrm{km}^{2} \\
1-3 \mathrm{~km} / \mathrm{km}^{2} \\
0.43-1.0 \mathrm{~km} / \mathrm{km}^{2} \\
0.06-0.43 \mathrm{~km} / \mathrm{km}^{2} \\
<0.06 \mathrm{~km} / \mathrm{km}^{2}\end{array}$ & Woodley 2000 \\
\hline
\end{tabular}

Note: Some road density figures were converted from $\mathrm{mi} / \mathrm{mi}^{2}$ to $\mathrm{km} / \mathrm{km}^{2}$ for consistency. 


\section{Road density in Nova Scotia}

In light of the generally negative impacts associated with roads and higher road densities on some native wild ife species and the implications for biodiversity conservation, it is important to understand the distribution and extent of roads and road density in Nova Scotia. GIS-based road density maps were created using road data from the Nova Scotia Geomatics Centre. Road density was represented by six density classes based on $\mathrm{km} / \mathrm{km}^{2}(0,0.01-0.06,0.06-0.6,0.6-1,1-3,>3)$ and mapped on a $1 \times 1 \mathrm{~km}$ grid. The classification scheme was adapted from that used in the Interior Columbian Basin Ecosystem Management Study (Woodley 2000), including a zero-road-density class to identify roadless areas. In addition, the $0.6 \mathrm{~km} / \mathrm{km}^{2}$ threshold value identified by Forman et al. (1997) was incorporated into the classification scheme in order to allow subsequent reclassification into areas above and below the threshold.

The road data acquired from the Nova Scotia Geomatics Centre were derived from aerial photography flown between 1987 and 1997. The roads were mapped at a scale of 1:10,000 and were assigned codes to represent the road type; there are approximately 50 recognized road types in Nova Scotia (Anonymous 1990). Other forms of utility corridors and linear developments such as survey and exploration cuts, power lines and pipelines were not included in the road classification or density calculation. The roads were then reclassified into six different categories to produce a roads layer: 1) major highways, 2) primary roads, 3) secondary roads, 4) seasonal roads, 5) active railroads, and 6) abandoned roads/railways, tracks, and trails. Once this was completed, a $1 \mathrm{~km}^{2}$ grid layer covering the entire province was created. The roads layer was then overlain on the grid layer and calculations were performed to determine the total length of roads within each square kilometer. Having calculated the road density for the grid layer, the density values were then reclassified into the aforementioned density classes $\left(0,0.01-0.06,0.06-0.6,0.6-1,1-3,>3 \mathrm{~km} / \mathrm{km}^{2}\right)$. This procedure was used to produce two density coverages. One employed all six of the different road, track and trail categories and thereby treated all road types as having equal impact in terms of the density calculation (Fig 1 ). The other employed only major highways, primary and secondary roads, and active railroads to calculate the density coverage (Fig 2). These two coverages were subsequently reclassified into areas above and below the threshold value of $0.6 \mathrm{~km} / \mathrm{km}^{2}$ (Fig 3 and 4).

The results of this exercise show that several areas of Nova Scotia are above the 0.6 $\mathrm{km} / \mathrm{km}^{2}$ threshold value of road density (Fig 3 and 4). Areas of highest road density exist along the coast, in the Halifax region, in the Annapolis Valley, and along the major highways such as the Trans Canada Highway 101 (Fig 2). The lowest road density classes occur in the interior region of southwestern Nova Scotia. When woods roads, cart tracks and trails are taken into account, the Cumberland-Colchester area has a relatively high road density (Fig 1). These road density patterns may be significant to biodiversity conservation in Nova Scotia. The province is also essentially bisected by Highway 101, fragmenting southwestern populations of wild ife from other populations north east of the highway. In addition, the narrow isthmus connecting Nova Scotia to New Brunswick is further constricted by a highway, other roads, and a railway, effectively isolating some wildlife populations in Nova Scotia from other populations in New Brunswick and the rest of North America. 


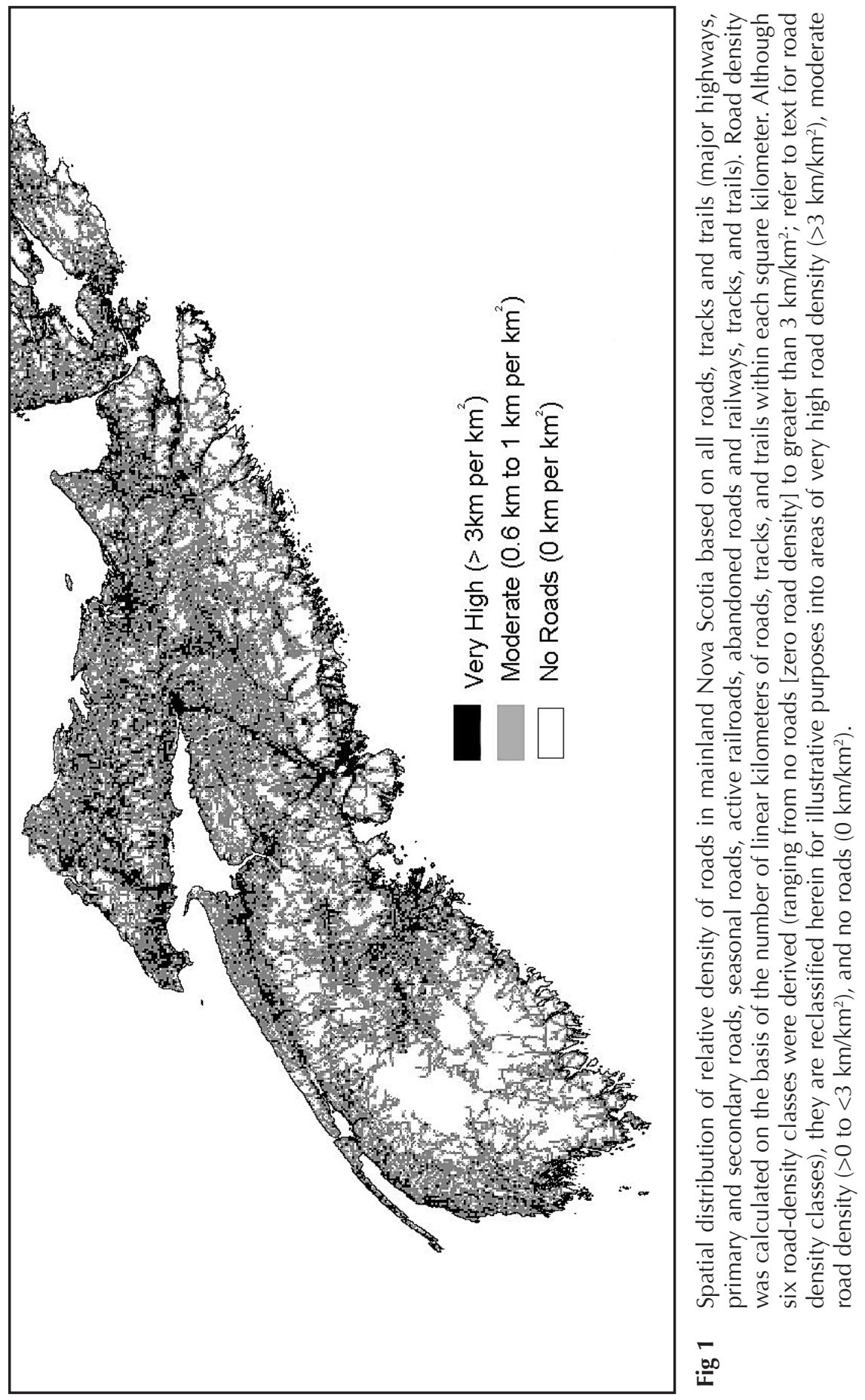




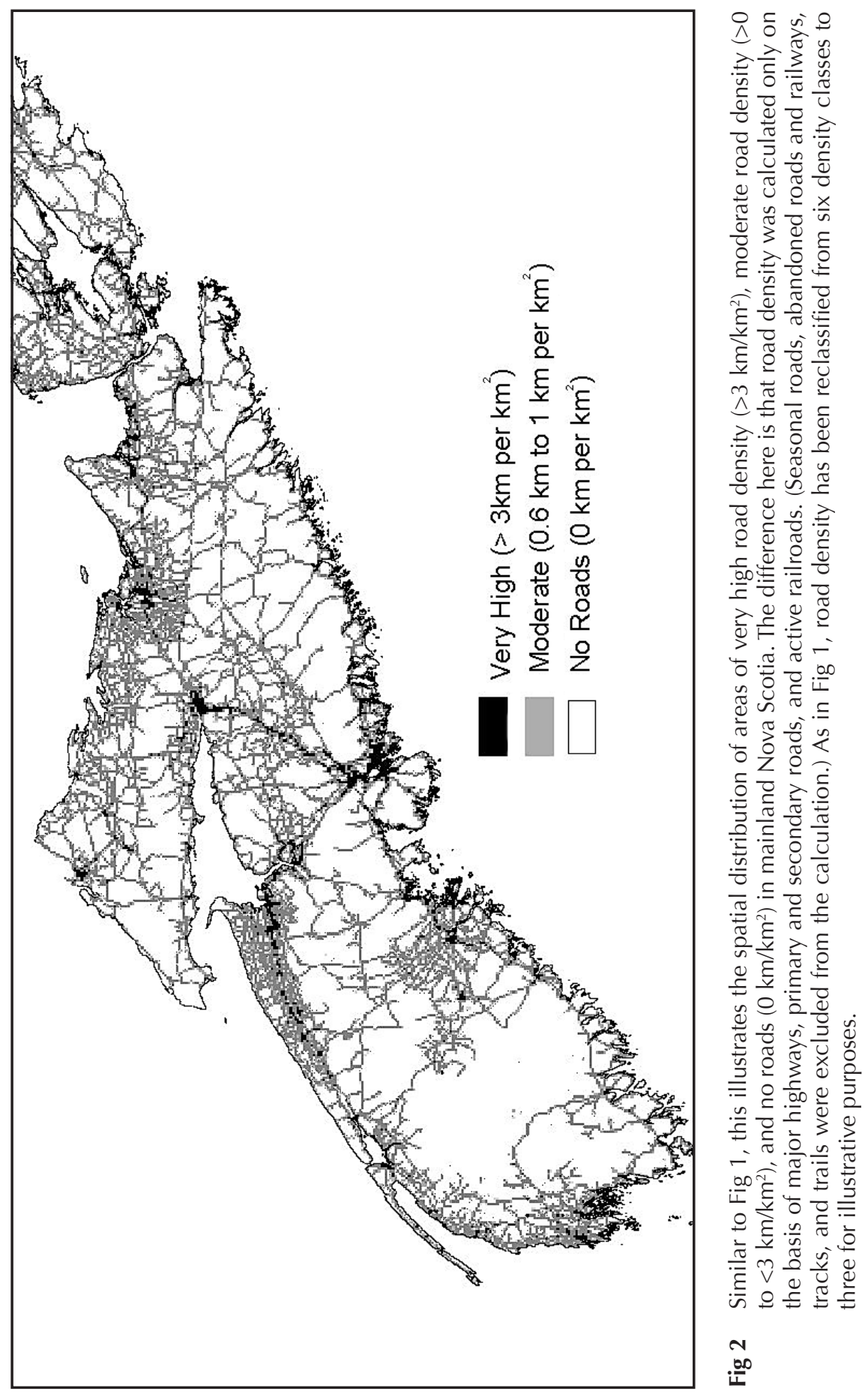




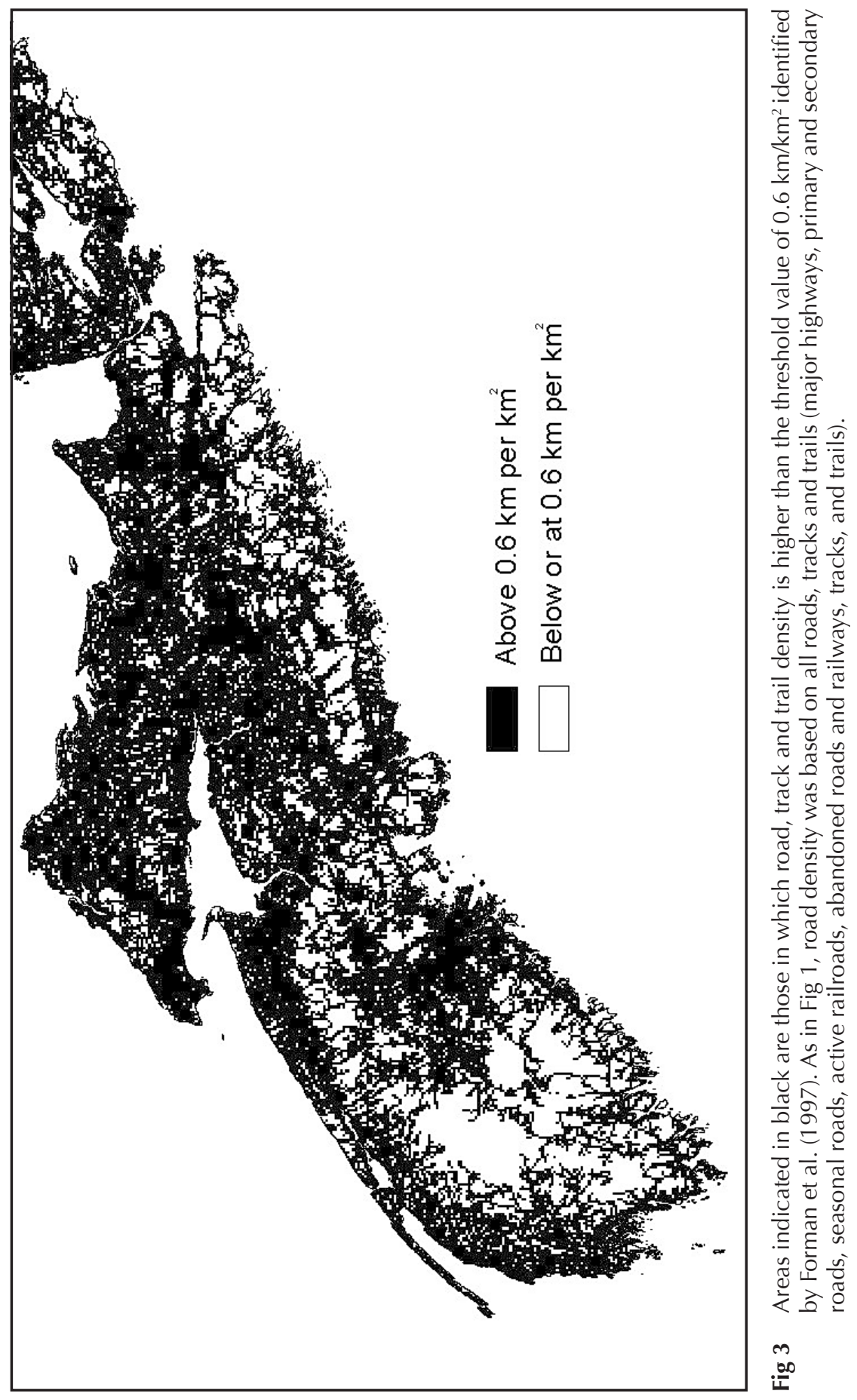




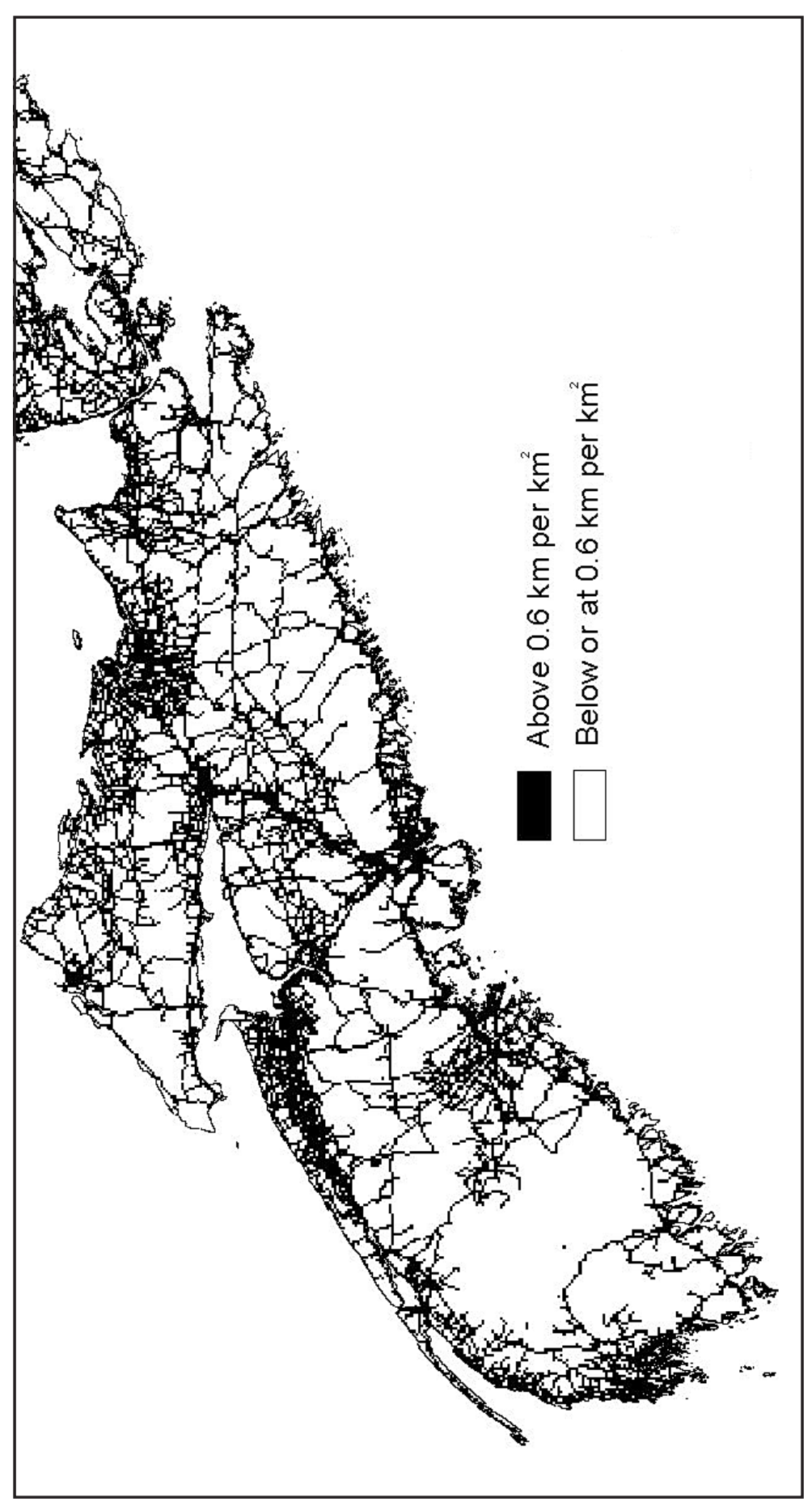

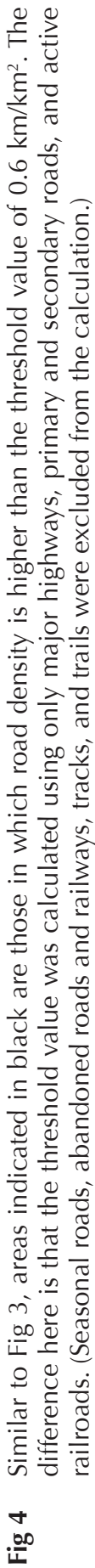




\section{Effects of road density on moose population viability and habitat selection in mainland Nova Scotia}

Road density factors affect population viability and habitat selection by or effectiveness for moose in mainland Nova Scotia (Snaith 2001, Snaith \& Beazley 2002, Snaith et al. 2001). For example, the small southwestern/Tobeatic population of moose is isolated from other populations by the section of Highway 101 running from Halifax to Windsor, thus increasing genetic, demographic and environmental risk factors (refer to Snaith \& Beazley (2004) for a map of moose distribution in NS). This situation is currently exacerbated by construction activities associated with twinning the Highway from Mount Uniacke to Windsor. High density of woods roads and trails in the Cumberland-Colchester area may result in some greater risk to the current relative stronghold of mainland moose from disease, competition, predation and illegal hunting. Further, the long-term viability of mainland moose populations may be at greater risk due to restricted migration and dispersal to and from New Brunswick and beyond. Road effects and road density may have been factors in the reduction and fragmentation of mainland moose populations, which have resulted in increased risk to both short and long term population viability.

Moose habitat suitability and selection in mainland Nova Scotia appear to be affected by road density (Snaith 2001, Snaith et al. 2001, MacKinnon 2001). Road density was selected as an index of human influence, and moose pellet distribution was selected as an indicator of winter moose distribution/habitat selection in Nova Scotia. The road density coverage (Fig 1 ) was overlain with habitat suitability index (HSI) and moose pellet distribution maps (Fig 5), and multivariate logistic regression analyses were used to examine the relationship between road density and habitat suitability values in predicting moose pellet presence.

Results indicate that road density is able to predict moose pellet distribution; a significant negative correlation suggests that as road density increased, the probability of moose pellet presence decreased (Snaith 2001, Snaith et al. 2001). All HSI values and individual habitat components, when combined with the effect of roads, could significantly predict pellet presence; however, many of the HSI values and habitat components alone, without taking into account road density, were unable to predict pellet presence.

Road density may be an important factor determining moose distribution and habitat selection. Thus, habitat suitability models conducted in areas with human activities should include considerations of road density. Although in this study road density was more significantly correlated with moose pellet presence/absence than was habitat suitability, there are many other factors that could influence the results. For example, factors such as acidification, pollution, and climate may also affect the presence or absence of moose in areas of greater or lesser road density. It is possible that the effects of higher road densities are stronger in combination with other stressors such as those that occur with species existing at the southern limits of their range, as is the case with moose in mainland Nova Scotia. Although there have been no other studies to specifically explore the correlation between road density and moose populations in Nova Scotia and other Atlantic provinces, the findings reported here (that moose pellet presence is negatively correlated with higher road densities) are consistent with studies in New Brunswick and Newfoundland that correlate hunting success with hunter access by roads and subsequent decreases in moose populations (Boer 1990, McLaren 2002). They are also consistent with findings elsewhere that suggest that for sensitive species such as large herbivores, road density is an accurate predictor of habitat effectiveness (Lyon 1983, Thiel 1985, Noss \& Cooperrider 1994, Noss et al. 1999). 


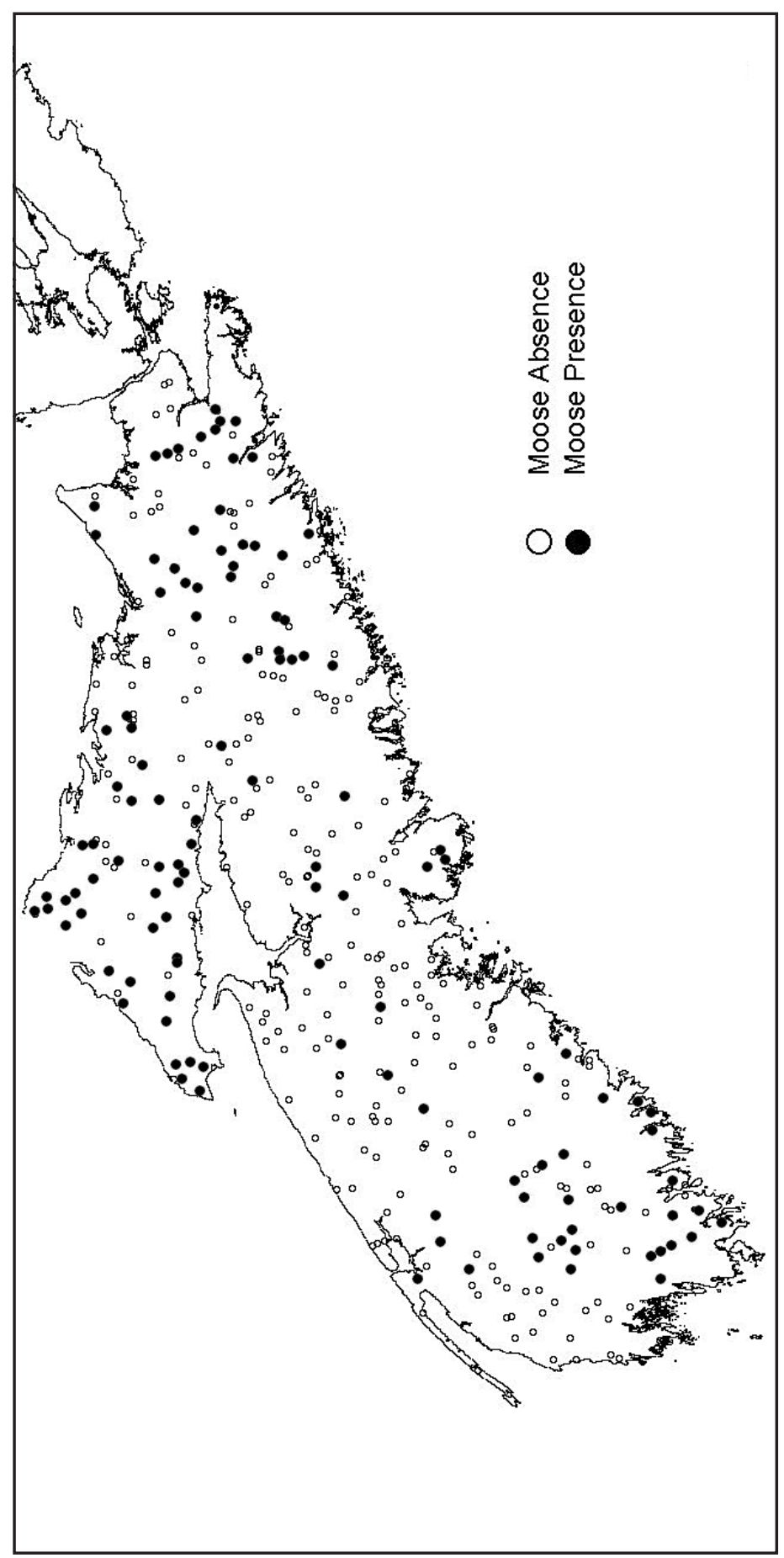

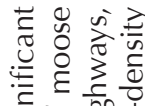

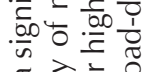

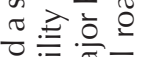

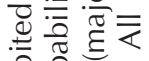

응 응 뜸

U⿱亠凶禸㔾

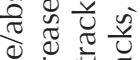

过兄

屯.

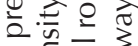

屯 $\frac{\overline{0}}{0} \frac{3}{\sigma}$

흥 홍

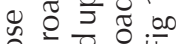

\& \&

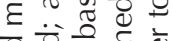

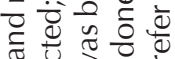

츤 3 츤

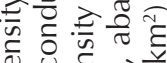

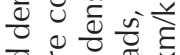

원융

고요

.

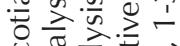

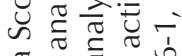

ว 5 ก

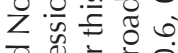

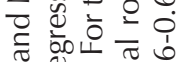

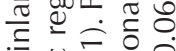

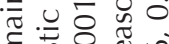

ह

.

U.

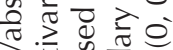

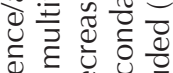

\& $\simeq \frac{U}{0}$

훠워

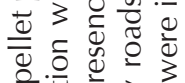

을 을

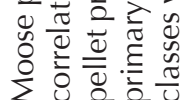

in 
Further research could examine the relative influences of various factors on moose distribution in mainland Nova Scotia and in neighboring areas. In the meantime, however, given the concerns over the status of moose in mainland Nova Scotia (Snaith 2001, Snaith \& Beazley 2002), areas with no roads or low road densities occupied by moose or containing otherwise suitable moose habitat on the mainland should be maintained in a relatively roadless and inaccessible state. New roads could be located to avoid critical habitat components; existing roads could be decommissioned following completion of operations; and, underpasses and overpasses could be constructed to allow movement across major highways. These recommendations are consistent with those of other authors studying the impacts of roads on wildlife species (Peek et al. 1987, Hogg 1990).

\section{Managing roads in wildlife habitat}

An increasing body of scientific evidence demonstrates the deleterious effects of roads on wildlife and underscores the importance of maintaining roadless areas. Clearly, road density must be kept below critical thresholds if many wildlife populations are to survive. In addition, existing roadless areas and areas of low road density are important refuges for sensitive wildlife species, such as large-bodied vertebrates and forest-interior species. Thus, any roads constructed in otherwise large, natural areas or through wildlife corridors will have significant negative effects even at lower road densities. The effects of roads extend more than $1 \mathrm{~km}$ from the road (Forman et al. 1997), creating a much larger disturbance area than the width of the actual roadbed. For these reasons, it is important to restrict new road and trail access into habitat areas for sensitive species such as moose, lynx and American marten in Nova Scotia.

Roadbeds could be retired and restored after logging and other temporary activities have been completed. In some critical areas, existing roads negatively affecting wildlife while providing minimal benefits to society could be eliminated. Wildlife crossings could be provided at key areas along major highways. For example, in Banff National Park underpasses at the Trans-Canada Highway are used by elk, black bear, wolf, coyote, cougar, lynx and bighorn sheep (Paquet \& Callaghan 1996, Gibeau \& Heuer 1996, Leeson 1996). Certain species such as grizzly bear, however, are not known to use these underpasses; thus, overpasses may better serve the needs of some species (Horesji 2001).

\section{Conclusion}

It is likely that roads exert a negative influence on moose and some other wildlife populations in Nova Scotia, as elsewhere. Increasing road density and intensity of use, as well as new access roads into large, natural areas and wildlife corridors have been demonstrated to cause significant negative effects on some species of wildlife in studies conducted elsewhere. Biodiversity conservation initiatives such as protected areas and recovery plans, forestry, wildlife and parks management, and provincial and regional land-use and transportation planning should take into consideration the direct and indirect effects of roads and road density on sensitive species of wildlife.

Many areas of Nova Scotia exceed the road density threshold $\left(0.6 \mathrm{~km} / \mathrm{km}^{2}\right)$ beyond which natural populations of some large vertebrates have been shown to decline. Road densities appear to affect the selection of habitat by moose. Road density may be among the key factors influencing habitat effectiveness, and thus critical habitat area and population viability, for moose in mainland Nova Scotia, as well as for other 
species sensitive to the effects of roads such as Canada lynx, American marten, and black bear. Additional research into road effects on wildlife species and ecosystems in Nova Scotia is warranted.

Road density appears to be an appropriate indicator for use in applications where maintenance of native biological diversity forms at least a portion of the management objectives. For example, in regions with various levels of human development and activity, areas with low road density may indicate those with greater potential value for wildlife. This is particularly the case if these areas are also of high habitat suitability in other respects such as forage, thermal and security cover, and denning, nesting or calving areas. However, in Nova Scotia, as in other regions, areas of low road density may also be areas with relatively lower ecological productivity, since these areas may be roadless because of their lower capacity to produce resources, for human enterprises, and thus may also provide low resource productivity for wildlife such as moose. It appears that in Nova Scotia, moose pellet presence is significantly correlated with habitat suitability only when road density is factored in, whereas moose pellet presence is significantly correlated with road density regardless of other habitat suitability factors. As a result, road density may be a better indicator of habitat effectiveness than are habitat suitability indices.

Although areas of low road density may not represent the richest or best areas in terms of net productivity or factors generally used to assess habitat suitability, they are likely to be the areas with the least road-disturbance effects on wildlife and may be preferentially selected by wildlife as a result. Thus, areas of low road density, especially those that also demonstrate other elements of habitat suitability, are potentially important areas for biodiversity conservation; they should be maintained either through wildlife, forestry or other landscape management practices or by designation as protected wilderness areas. New road construction could be minimized, especially in roadless areas or areas of low road densities, and areas important as wildlife habitat and corridors. Roads could be decommissioned and restored after use to minimize access and other adverse effects. Further, wildlife underpasses and overpasses could be constructed on high-use primary and secondary roads and highways so as to minimize collision mortality and indirect negative effects on habitat, wildlife movement, and individuals and populations of wildlife. Road density appears to be a good indicator of human impacts (habitat conversion, degradation and fragmentation; hunting, trapping, fishing, and poaching; roadkill mortality; predation and competition) on sensitive species of wildlife and, consequently, of habitat effectiveness. Thus, measures of road density have utility for identifying areas of conservation value to wildlife.

\section{Acknowledgements}

The EJLB Foundation provided funding and the Nova Scotia Department of Natural Resources, Wildlife Division provided data on moose pellet distribution for the research. The authors would also like to thank Scott Brown for editorial assistance and an anonymous reviewer for constructive comments that have contributed to improvements in the paper. 


\section{References}

Anonymous (1990) NS 1:10,000 Enhanced Topobase Feature Codes, Doc 3552, June 25, 1990 http://www.gov.ns.ca/snsmr/land/programs/post/manual/default.asp

Anonymous (2000) Interim Special Management Practices for Lynx in Nova Scotia. Revision of Lynx SMP. Nova Scotia Department of Natural Resources, Halifax, NS.

Boer AH (1990) Spatial distribution of moose kills in New Brunswick. Wildl Soc Bull 18: 431-434

Boer AH (2002) (AMEC Earth and Environmental, Fredericton) Personal communication

Brocke RH, O'Pezio JP, Gustafson KA (1988) A forest management scheme mitigating impact of road networks on sensitive wild life species. In: Degraaf RM, HealyWM (eds) Is forest fragmentation a management issue in the northeast? GTR-NE-140, United States Department of Agriculture, Forest Service, Northeastern Forest Experimental Station, Radnor, PA: 13-17

Brody AJ, Pelton MR (1989) Effects of roads on black bear movements in western North Carolina. Wildl Soc Bull 17:5-10

Buskirk SW, Ruggiero LF, Krebs CJ (2000) Habitat fragmentation and interspecific competition: implications for lynx conservation. http://www.Fs.fed.us/rm/pubs/ rmrs_gtr30/lynx/chap4.pdf.

Canadian Wildlife Service (1997) Endangered species in Canada. Environment Canada, Ottawa

CESCC (Canadian Endangered Species Conservation Council) (2001) Wild Species 2000: the general status of species in Canada. CESCC, Department of Public Works and Government Services, Ottawa

COSEWIC (Committee on the Status of Endangered Wildlife in Canada) (2003) Canadian species at risk, November 2003. COSEWIC, Canadian Wildlife Service, Environment Canada, Ottawa

Crete M, Taylor RJ, Jordan PA (1981) Optimization of moose harvest in southwestern Quebec. J Wildl Manag 45:598-611

Forman RTT (1995) Land mosaics: the ecology of landscapes and regions. Cambridge University Press, Cambridge

Forman RTT, Hersperger AM (1996) Road ecology and road density in different landscapes, with international planning and mitigation solutions. In: Evink GL, Garrett P, Zeigler D, Berry J (eds) Trends in addressing transportation related wildlife mortality. Florida Department of Transportation Report FL-ER-58-96, p 1-22

Forman RTT, Friedman DS, Fitzhenry D, Martin JD, Chen AS, Alexander LE (1997) Ecological effects of roads: toward three summary indices and an overview of North America. In: Canter K (ed) Habitat fragmentation and infrastructure. Minister of Transport and Public Works and Water Management, Delft, Netherlands, p 40-54

Gibeau ML, Heuer K (1996) Effects of transportation corridors on large carnivores in the Bow River Valley, Alberta. Florida Department of Transportation Report FLER-58-96, p 75-89

Gilpin M, SouléME (1986) Minimum viable populations: processes of species extinction. In: Soulé ME (ed) Conservation biology: the science of scarcity and diversity. Sinauer Associates, Sunderland, MA, p 19-34

Gucinski H, Furniss M, Ziermer R, Brookes M (2001) Forest Service roads: a synthesis of scientific information. Gen Tech Rep PNW-GTR-509.1, United States Department of Agriculture, Forestry Service, Pacific Northwest Research Station, Portland, OR

Hobbs RJ, Huenneke LF (1992) Disturbance, diversity, and invasion: implications for conservation. Conserv Biol 6:324-337 
Hogg D (1990) Moose management: the forest habitat. In: Ontario Department of Natural Resources (ed) The moose in Ontario, Book 1. Moose biology, ecology and management. Queen's Printer for Ontario, Toronto, p 30-33

Jalkotzy MG, Ross PI, Nasserden MD (1997) The effects of linear developments on wildlife: a review of selected scientific literature. Arc Wildlife Services Ltd, prepared for Canadian Association of Petrolroleum Producers, Calgary

Jensen WF, FullerTK, Robinson WL (1986) Wolf Canis lupus distribution on the OntarioMichigan border near Sault Ste. Marie. Can Field-Nat 100:363-366

Knight RL, Gutzwiller K (eds) (1995) Wildlife and recreationists: coexistence through research and management. Island Press, Washington, DC

Leeson BF (1996) Highway conflicts and resolutions in Banff National Park, Alberta. Florida Department of Transportation Report FL-ER-58-96, p 91-96

Lyon LJ (1983) Road density models describing habitat effectiveness for elk. J For 81: 592-595

Lyon LJ (1984) Road effects and impacts on wildlife and fisheries. Forest Transportation Symposium December 11-13, 1984 Casper, Wyoming, 7th Proceedings. United States Department of Agriculture, Forest Service, Region 2, Denver, CO

MacKinnon F (2001) Analysis of moose habitat on mainland Nova Scotia: the development of two GIS tools for moose habitat suitability and moose habitat extraction. Applied Geomatics Research Group, Centre of Geographic Sciences, Lawrencetown, NS

May RM, Lawton HJ, Stork NE (1995) Assessing extinction rates. In: Lawton JH, May RM (eds) Extinction rates. Oxford University Press, Oxford, UK, p. 1-24

McLaren B (2002) (Department of Natural Resources, Government of Newfoundland and Labrador, Gander) Personal communication

Mech LD (1989) Wolf population survival in an area of high road density. Am Midl Nat 121:387-389

Mech LD, Fritts SH, Radde GL, Paule WJ (1988) Wolf distribution and road density in Minnesota. Wildl Soc Bull 16:85-87

Miller SG, Knight RL, Miller CK (1998) Influence of recreational trails on breeding bird communities. Ecol Appl 8:162-169

Noss RF (1995) Maintaining ecological integrity in representative reserve networks. World Wildlife Fund Canada, Toronto

Noss RF, Cooperrider AY (1994) Saving nature's legacy: protecting and restoring biodiversity. Island Press, Washington, DC

Noss RF, Dinerstein E, Gilbert B, Gilpin M, Miller BJ, Terborgh J, Trombulak S (1999) Core areas: where nature reigns. In: Soulé ME, Terborgh J (eds) Continental conservation: scientific foundations of regional reserve networks. Island Press, Washington, DC, p 99-128

O'Neil P (2000) Treasures of the wild: Standing guard over Cape Breton's disappearing lynx and pine martin. The Cape Bretoner 8:16-18

Paquet P, Callahan C (1996) Effects of linear developments on winter movements of gray wolves in the Bow River Valley of Banff National Park, Alberta. Florida Department of Transportation Report FL-ER-58-96, p 51-73

Peek JM, Pierce DJ, Graham DC, Davis DL (1987) Moose habitat use and implications for forest management in northcentral Idaho. SwedWild Res Viltrevy Suppl 1:195-199

Pimm SL, Ayers M, Balmford A, Branch G and 29 others (2001) Environment - Can we defy nature's end? Science 293:2207-2208

Pimm SL, Russell GJ, Gittleman JL, Brooks TM (1995) The future of biodiversity. Science 269: 347-350 
Prescott WH (1968) A study of winter concentration areas and food habits of moose in Nova Scotia. MSc thesis, Acadia University, Wolfville, NS

Prescott WH (1974) Interrelationships of moose and deer of the Genus Odocoileus. Nat Can (Que) 101:493-504

Pulsifer MD, Nette TL (1995) History, status and present distribution of moose in Nova Scotia. N Am Moose Conf Worksh 31:209-219

Rempel RS, Elkie PC, Rodgers AR, Gluck MJ (1997) Timber-management and naturaldisturbance effects on moose habitat: landscape evaluation.JWildl Manag 61:517-524

Rudis VA (1995) Regional forest fragmentation effects on bottomland hardwood community types and resource values. Landsc Ecol 10:291-307

Sage RS, Tierson WC, Mattfeld GF, Behrend DF (1983) White-tailed deer visibility and behavior along forest roads. J Wildl Manag 47:940-962

Schowalter TD (1988) Forest pest management: a synopsis. Northwest Environ J 4:313-318

Shaffer ML (1981) Minimum population sizes for species conservation. BioScience 31:131-134

Snaith T (2001) The status of moose in mainland Nova Scotia: Population viability and habitat suitability. MES thesis, Dalhousie University, Halifax

Snaith T, Beazley K (2002) Moose (A/ces alces americana Peterson) as a focal species for reserve design in Nova Scotia, Canada. Nat Areas J 22:235-240

Snaith T, Beazley K (2004) Population viability: theory and application to moose in mainland Nova Scotia. N Am Moose Conf Worksh 38: (in press)

Snaith T, Beazley K (2004) The distribution, status and habitat associations of moose (Alces alces americana) in mainland Nova Scotia. Proc NS Inst Sci 42:263-317

SnaithT, Beazley K, MacKinnon F, Duinker P (2004) Habitat suitability analysis for moose (Alces alces americana) in Nova Scotia. N Am Moose Conf Worksh 38: (in press)

Soulé ME (1991) Conservation: tactics for a constant crisis. Science (Wash DC) 253:744-253

Telfer ES (1968) The status of moose in Nova Scotia. J Mammal 49:325-326

Telfer ES, Cairns AL (1986) Resource use by moose versus sympatric deer, wapiti and bison. N Am Moose Conf Worksh 22:113-137

Terborgh J, Winter B (1980) Some causes of extinction. In: Soulé ME, Wilcox ME (eds) Conservation biology: an evolutionary-ecological perspective. Sinauer Associates, Sunderland, MA, p 119-134

Thiel RP (1985) Relationship between road densities and wolf habitat suitability in Wisconsin. Am Midl Nat 113: 404-407

Timmerman HR, Gollath R (1982) Age and sex structure of harvested moose related to season manipulation and access. N Am Moose Conf Worksh 18:301-328

Usher MB (1988) Biological invasions of nature reserves: a search for generalizations. Biol Conserv 44:119-135

Van Dyke FB, Brocke RH, Shaw HG, Ackerman BB, Hemker TP, Lindzey FG (1986) Reactions of mountain lions to logging and human activity. JWildl Manag 50:95-102

Williamson MH, Fitter A (1996) The characters of successful invaders. Biol Conserv 78:163-170

Woodley S (2000) (Parks Canada, Ottawa) Personal communication 


\begin{tabular}{ll} 
Appendix 1: & Species list \\
\hline American marten & Martes americana \\
black bear & Ursus americanus \\
bobcat & Lynx rufus \\
fisher & Martes pennanti \\
lynx & Lynx canadensis \\
moose & Alces alces americana \\
river otter & Lutra canadensis \\
white-tailed deer & Odocoileus virginianus \\
wolf & Canis lupus \\
wolverine & Gulo gulo \\
\hline
\end{tabular}

